\title{
On the vectors of cutaneous leishmaniasis in the Central Amazon of Brazil. 4. Sand fly emergence from a "terra firme" forest floor (1)
}

\author{
Jorge R. Arias ( ${ }^{2}$ )
}

Rui A. de Freitas $\left({ }^{2}\right)$

\begin{abstract}
Over $30 \%$ of the sand flies collected in emergence traps from a "terra firme" forest in the Amazon Basin of Brazil were known vectors of cutaneous leishmaniasis. Fifteen species of sand flies were collected from a region where at least 50 species are known to occur. The majority of specimens were taken from traps set during the month of November. It was estimated that $100 \mathrm{~m}^{2}$ of terra firme forest will only produce an average of. 4.1 sand flies per day; however, this productivity may reach as hign as 14 sand flies per $100 \mathrm{~m}^{2}$ per day.
\end{abstract}

\section{INTRODUCTION}

Silvatic breeding places of sand files in the Neotropics has been the subject of several studies in the past, primarily in Panama (Hanson, 1961; Thatcher, 1963; Rutledge \& Ellenwood, 1975). In the regions where the etiological agent for cutaneous leishmaniasis (commonly known as "pian-bois") is Leishmania braziliensis guyanensis, the breeding place of the vector species has been sought with little success (Arias, unpublished data). Rutledge \& Ellenwood (1975) showed fair success in locating breeding sites for some Panamanian sand fiies, assessing the forest floor for these insects.

This paper presents the results of a long term capturing program of sand flies from a terra firme forest in the Central Amazon of Brazil, utilizing soil emergence traps.

\section{MATERIALS AND METHODS}

The soil emergence traps used are those described in Penny \& Arias (1982). Three traps were set per month on the first week of each of the nine months during the study. Those traps set during the first month stayed on the same $\mathrm{m}^{2}$ plot for 13 months; those set on the second month stayed for 12 months; those set on the ninth month only stayed out for four months.

The study area was a $90 \times 40$ meter area which was subdivided into 36 (10X10 meter) plots (fig. 1). Plots where traps were to be set each month were randomly selected prior to the study. When a trap was to be placed on the ground, open areas of forest floor were selected and the vegetation where the traps were to be set was trimmed to $25 \mathrm{~cm}$. above the ground without disturbing the ground that was to be under the traps. After they were in place, the sides of the traps were braced with soil from the outside to ensure a total seal around the bottom. At the top of each trap, a plastic collecting device was partialiy filled with a $5 \%$ picric acid solution. Within each trap, in the ground, a pitfall trap, (also with picric acid) was set to capture the non-flying arthropods that may be inside the trap litter

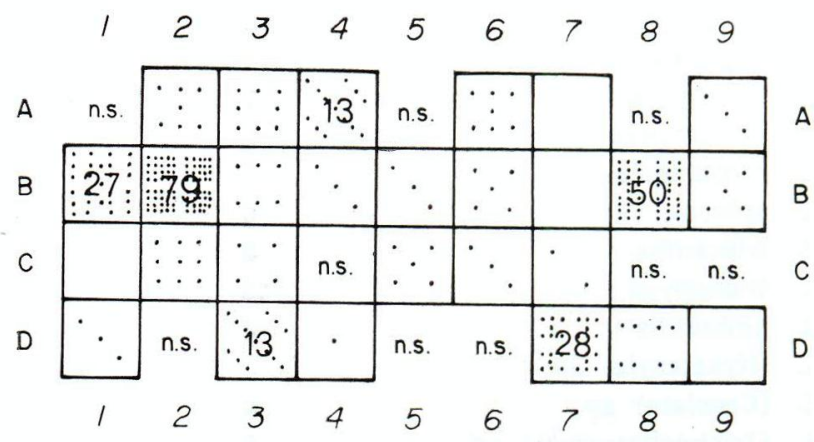

Fig. 1 - Distribution of sand flies per plot of sample area in a terra firme forest in the Central Amazon of Brazil.

(1) - This research was partly supported by CNPq's Grandes endemias grant 2222.8.087/80 and INPA's project 3017 . (2) - Instituto Nacional de Pesquisas da Amazônia Manaus. 
once it was set. All traps were examined and the trapped insects in them removed on a weekly basis.

\section{RESUlts}

A total of 300 sand flies (75 males and

225 females), comprising 15 species, were captured during a 13 month period from a total of 243 trap months (table 1.). The species most frequently taken were: Lutzomyia begonae, $L$. anduzei, L. rorotaensis, $L$. umbratilis and L. trichopyga, which accounted for $83.2 \%$ of all the sand flies captured. Overall sand fly production was low, yielding an estimated total of 1.24 sand flies per trap per month. All traps did not produce an equal number of sand flies, indicating a seasonal emergence from the forest floor (fig. 2). Traps $1 B, 2 B$ and $8 \mathrm{~B}$, which represent three of the 4 plots of greatest sand fly production, were set on the same day at the beginning of the month of November. Traps 3A, 4A, and 7D, which were set during the month of October, were the second group of traps that exhibited greatest production of sand flies. These six traps, along with trap 3D (set in December) captured 74\%

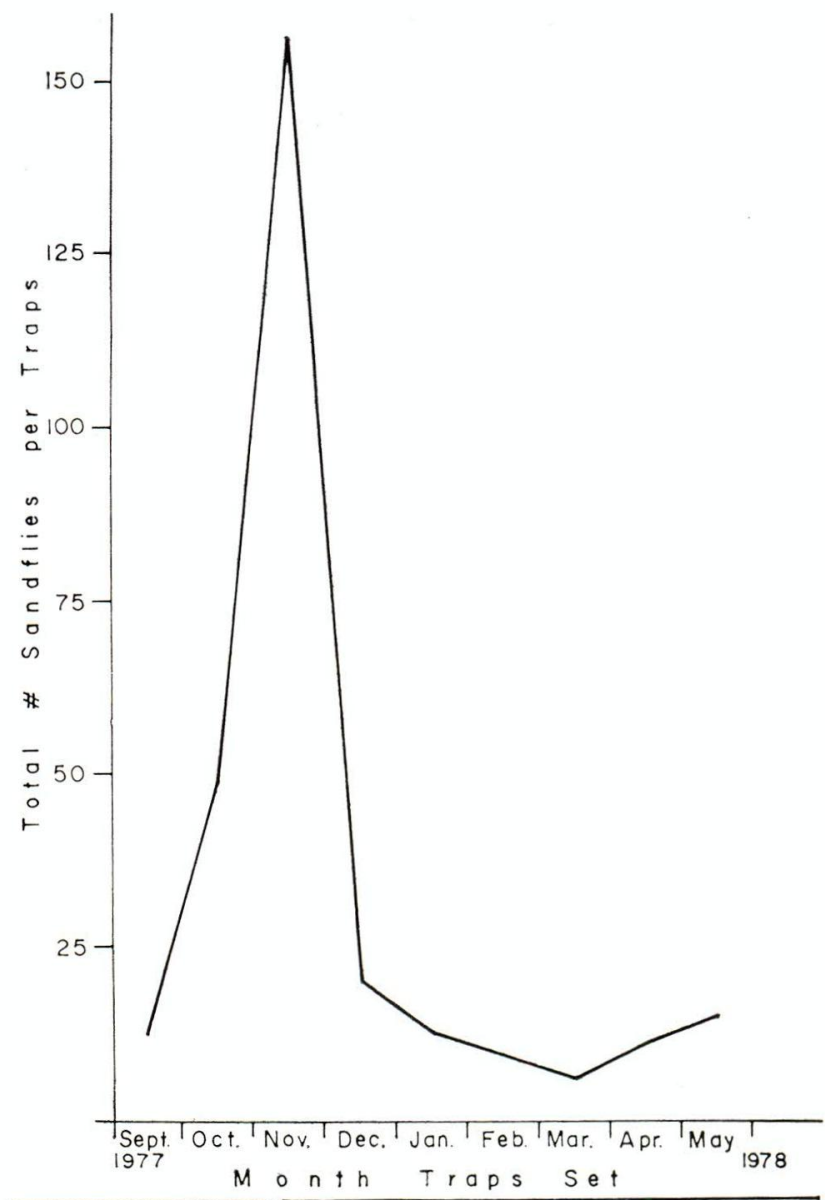

Fig. 2 - Incidence of sand flies captured in emergence traps in a terra firme forest in the Central Amazon of Brazil.

TABLE 1 - Species composition and frequency of sand files captured from emergence traps in a terra firme forest floor in the Central Amazon of Brazil.

\begin{tabular}{|c|c|c|c|c|}
\hline species & ô $\hat{O}^{-1}$ & 우 우 & $\%$ of total & $\begin{array}{c}\text { estimated } \\
\mathrm{N} .^{\circ} / \text { Trap / mo. }\end{array}$ \\
\hline Lutzomyia anduzei & 21 & 34 & 18.3 & 0.226 \\
\hline L. begonae & 1 & 69 & 23.3 & 0.288 \\
\hline L. longispina & 7 & 4 & 3.7 & 0.045 \\
\hline L. monstruosa & 2 & 3 & 1.7 & 0.021 \\
\hline L. rorotaensis & 7 & 47 & 18.0 & 0.222 \\
\hline L. spinosa & 0 & 1 & 0.3 & 0.004 \\
\hline L. triacantha & 0 & 2 & 0.7 & 0.008 \\
\hline L. trichopyga & 13 & 18 & 10.3 & 0.127 \\
\hline L. umbratilis & 6 & 34 & 13.3 & 0.165 \\
\hline L. (Nyssomyia) sp. & 4 & 4 & 2.7 & 0.033 \\
\hline L. (Cruciata) sp. & 4 & 1 & 1.7 & 0.021 \\
\hline L. (Trichophoromyia) $\mathrm{sp}$. & 6 & 2 & 2.7 & 0.033 \\
\hline L. $s p$ & 2 & $\mathbf{0}$ & 0.7 & 0.008 \\
\hline Psychodopygus davisi & $\mathbf{0}$ & 1 & 0.3 & 0.004 \\
\hline P. paraensis & $\mathbf{0}$ & 2 & 0.7 & 0.008 \\
\hline P. squamiventris & 2 & 3 & 1.7 & 0.021 \\
\hline TOTAL & 75 & 225 & 100 & 1.235 \\
\hline RATIO & 1 & 3 & 100 & 1.235 \\
\hline
\end{tabular}


of all the sand flies taken during the course of the study. The November traps alone took over $50 \%$ of all the sand fiies captured.

\section{Discussion}

Rutledge and Ellenwood (1975) estimated a production of 24 sand flies per $100 \mathrm{~m}^{2}$ per day from a Panamanian forest floor utilizing the same technique, differing only in the time they left each trap on the same site. We, on the other hand, averaged an equivalent of 4.1 sand flies per $100 \mathrm{~m}^{2}$ per day: if we considered only those traps set during the month of November, which were the ones which produced the most sand flies, these could have yielded an estimated 14 sand fiels per $100 \mathrm{~m}^{2}$ per day.

We feel that this data, along with the results of light trap captures which were carried out simultaneously (Penny \& Arias, 1982), suggests there is a peak emergence of sand flies during the beginning of the rainy season in the Manaus area.

Emergence traps for sand flies in the Neotropics does not seem to be a promising method of assessing the population, and it does not appear to produce any species that are difficult to obtain by other trapping techniques. Nevertheless, it suggests that the open forest floor is not one of the major breeding sites for sand flies.

\section{ACKNowledgrients}

We would like to thank Mr. João Ferreira Vidal for field support, and Artemio Coelho da Silva for technical work.

\section{Resumo}

Mais de $30 \%$ dos flebótomos coletados em armadilhas de eclosão de uma floresta de Terra Firme na Bacia Amazônica do Brasil eram vetores de leishmaniose cutânea. Quinze espécies foram coletadas de uma região de onde são conhecidas mais de cinqüenta espécies. A maioria dos flebótomos foram coletados nas armadilhas colocadas durante o mês de novembro. Estimou-se que de cada área de $100 \mathrm{~m}^{2}$ de solo aberto da floresta de terra firme são produzidos 4,1 flebótomos por dia, mais, considerando a época de maior produção, este número pode atingir até 14 flebótomos $/ \mathrm{m}^{2} / \mathrm{dia}$.

\section{REFERENCES}

HANSON, W.J.

1961 - The breeding places of Phlebotomus in Panama (Diptera: Psychodidae). Annals Ent. Soc. Amer., 54: 317-322.

PENNY, N.D. \& ARIAS, J.R.

1982 - Insects of an Amazon Forest. Columbia Univ. Press N.Y. 269pp.

RUTLEDGE, L.C. \& ELLENWOOD, D.A.

1975 - Production of Phlebotomine sandflies on the open forest floor in Panama: The Species Complement. J. Env. Ent., 4: 71-77.

THATCHER, V.E.

1968 - Arboreal breeding sites of Phlebotomine sandflies in Panama: Ann. Ent. Soc. Amer., 61 (5): 1141-1143.

(Aceito para publicação em 23/04/82) 